\title{
Differentiating Lymphoblastic Lymphoma and Ewing's Sarcoma: Lymphocyte Markers and Gene Rearrangement
}

\author{
Metin Ozdemirli, M.D, Ph.D., Julie C. Fanburg-Smith, M.D., Dan-Paul Hartmann, Ph.D., \\ Norio Azumi, M.D., Ph.D., Markku Miettinen, M.D. \\ Department of Pathology (MO, DH, NA), Georgetown University Medical Center, Washington, D.C.; and \\ Department of Soft Tissue Pathology (JCF-S, MM), Armed Forces Institute of Pathology, Washington, D.C.
}

We encountered a child with an intraosseous small round cell tumor that was negative for LCA, CD20 (L26), and CD3 and positive for vimentin, CD99 (MIC-2), and periodic acid-Schiff. The tumor exhibited rosette-like formations. This case was initially interpreted as Ewing's sarcoma (ES); however, additional studies revealed positivity for $\mathrm{CD} 79 \mathrm{a}, \mathrm{CD} 43$, and TdT expression, and an immunoglobulin heavy chain gene rearrangement (IgH-R) by polymerase chain reaction (PCR) established this to be a precursor B-lymphoblastic lymphoma. Because the differential diagnosis of ES and lymphoblastic lymphoma can be difficult and the differential diagnostic value of leukocyte antigens and immunoglobulin heavy chain gene rearrangement studies have not been fully evaluated, we conducted a more extensive investigation on 33 (21 soft tissue and 12 intraosseous) ES cases. Cases were retrieved from the files of the Department of Pathology at Georgetown University and from the Soft Tissue Registry of the Armed Forces Institute of Pathology. The cases were studied by light microscopy, immunohistochemistry, and PCR for IgH-R and T cell receptor gamma chain gene rearrangement $(T \gamma-R)$. There were 17 females and 16 males; the mean age was 29.3 years. Locations included the extremities $(n=$ 17) and trunk $(n=16)$. All cases fit the ES spectrum by light microscopy and immunohistochemistry, as previously determined, and were negative for lymphoid markers (LCA, CD3, CD20, CD43, CD79a, and TdT), CD10 and CD34. CD99 was positive in 31/33 and bcl-2 was weakly positive in 13/33 cases. All 21 cases studied for gene rearrangements by PCR were negative for IgH-R and T $\gamma$-R. Distinction of in-

Copyright (C) 2001 by The United States and Canadian Academy of Pathology, Inc.

VOL. 14, NO. 11, P. 1175, 2001 Printed in the U.S.A.

Date of acceptance: July 21, 2001.

Address reprint requests to: Metin Ozdemirli, M.D., Ph.D., Department of Pathology, Georgetown University Medical Center, 3900 Reservoir Road, N.W., Washington, DC 20007; fax: 202-687-8935. traosseous lymphoblastic lymphoma from ES may be difficult because lymphomas may occasionally exhibit unexpected morphologic and immunophenotypic properties including LCA, CD3 and CD20 negativity and cytokeratin positivity. Additional analysis using CD79a, CD43, TdT, and PCR should be performed to avoid misdiagnosis. True ES is negative for lymphoid markers including CD79a, CD43, and TdT, as well as for IgH-R and T $\gamma$-R.

KEY WORDS: Ewing's sarcoma, Lymphoid markers, Lymphoma.

Mod Pathol 2001;14(11):1175-1182

This study was prompted by a case of a small round cell tumor of the tibia in a 7-year-old girl, who was initially interpreted as Ewing's sarcoma (ES) because of rosette-like formations (Fig. 1), positivity for CD99 (MIC-2), cytokeratin, vimentin and periodic acidSchiff and negativity for LCA, CD3, and CD20 (L26) (Fig. 2). The differential diagnosis morphologically included lymphoma. Additional studies, including immunohistochemical stains for CD79a, CD43, and TdT (Fig. 3) and polymerase chain reaction (PCR) for immunoglobulin heavy chain gene rearrangement (IgH$\mathrm{R})$, definitively established this tumor to be a precursor B-lymphoblastic lymphoma.

Intraosseous lymphoblastic lymphomas may be confused with Ewing's sarcoma clinically and pathologically (1-4) and a limited panel of antibodies can lead to an erroneous diagnosis, particularly in children $(4,5)$. To determine to what extent lymphoid markers should be analyzed to exclude lymphoma with certainty before diagnosing ES, we investigated 33 cases of ES for expression of lymphoid markers and immunoglobulin heavy chain and T-cell receptor gamma-chain gene rearrangements. Although in a previous study, five cases of ES were reported to be negative for LCA (6), and in a recent study, certain lymphoid markers were reported to be negative in 17 ES cases (5), we conducted a more extensive investi- 


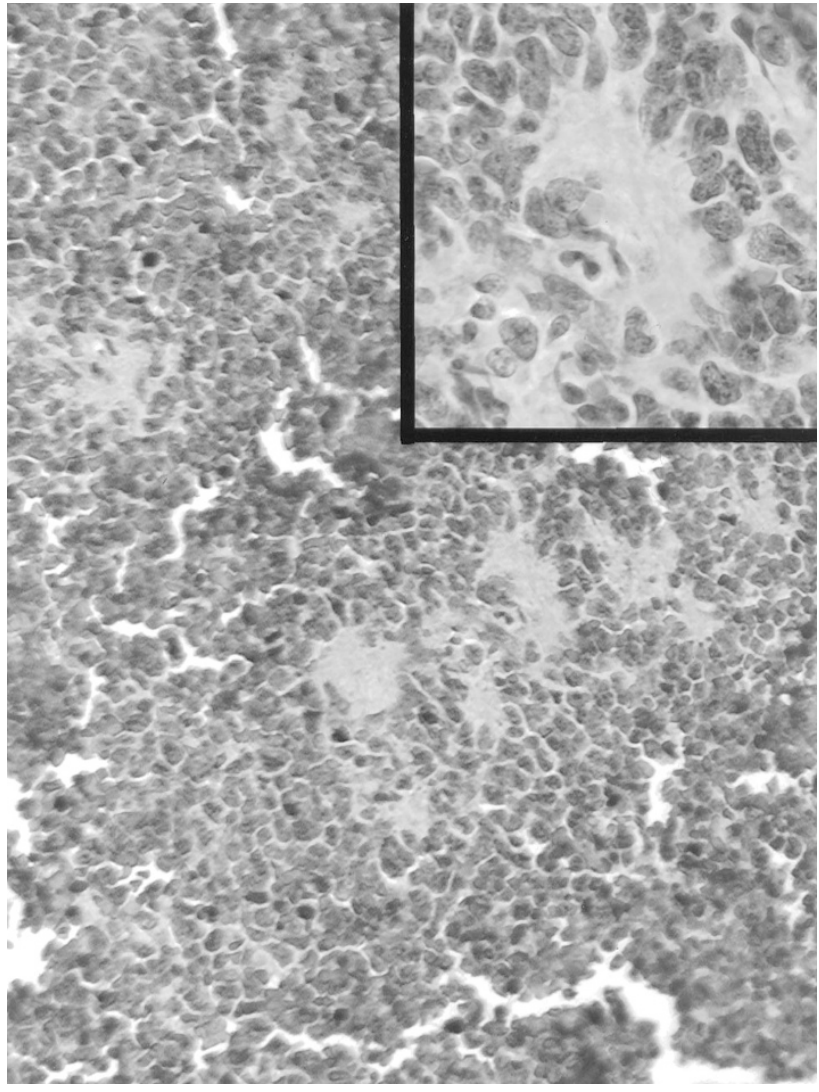

FIGURE 1. Lymphoblastic lymphoma with rosette-like formations mimicking Ewing's sarcoma $(\mathrm{ES})(\times 100)$, inset higher magnification $(\times 400)$.

gation on 33 ES cases including gene rearrangement studies. These additional findings have not been previously reported.

\section{MATERIALS AND METHODS}

\section{Cases}

Thirty-three (21 soft tissue and 12 intraosseous) ES cases were obtained from the files of the Armed Forces Institute of Pathology and Pathology Department of Georgetown University Medical Center.

\section{Light Microscopy and Immunohistochemistry}

Histologic sections were prepared from $10 \%$ formalin-fixed, paraffin-embedded tissue and stained with hematoxylin-eosin, and periodic acid Schiff stains with and without diastase-digestion. Immunohistochemical stains were carried out on formalin-fixed, paraffin-embedded tissue using the avidin-biotin technique with diaminobenzidine as a chromogen on an automatic immunostainer (TechMate 1000, Ventana Medical Systems, Tucson, AZ) (7). The following monoclonal antibodies were used: antibodies against CD45, UCHL-1, CD34, CD79a, CD20 (L26), S-100, HMB-45, NSE (neuron specific enolase), EMA (epithelial membrane anti-

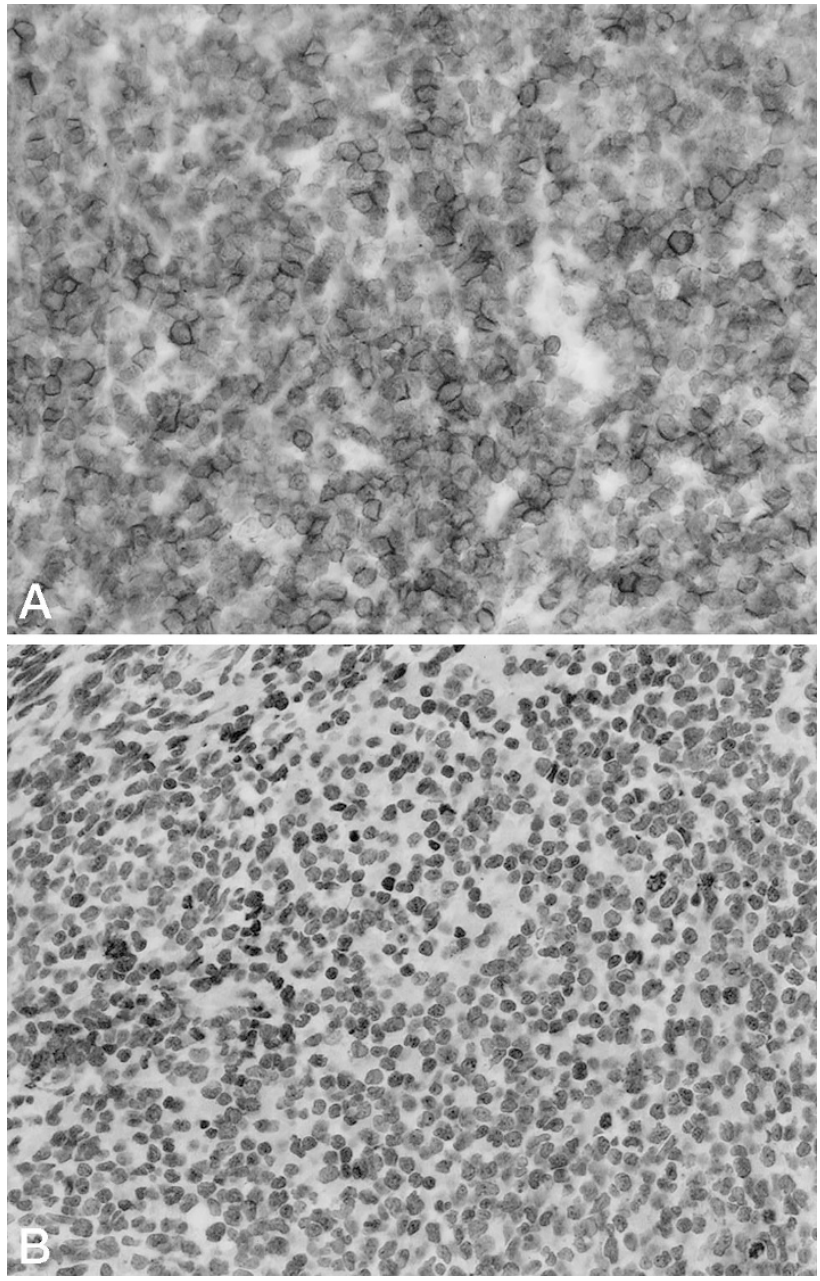

FIGURE 2. Lymphoma cells are positive for CD99 (MIC-2) (A) $(\times 400)$ and negative for CD20 $(\mathbf{B})(\times 200)$.

gen), smooth-muscle actin, vimentin, and desmin (purchased from DAKO, Carpinteria, CA), CD99 (O13) (from Signet, Dedham, MA), CD10 (from Novocastra Laboratories, Newcastle, UK), Leu 7, and CD43 (Leu 22) (from Becton-Dickinson, San Jose, CA), CD43 (MT-1) (from Boehringer Mannhein, Indianapolis, IN), chromogranin, synaptophysin, neurofilament, and keratin (a cocktail of AE1/AE3, CAM 5.2, and 35 $\beta \mathrm{H} 11$ ) (from Ventana Medical Systems, Tucson, AZ). In addition, the following polyclonal antibodies were used: antibodies against CD3 (from DAKO, Carpinteria, CA), and TdT (terminal deoxynucleotidyl transferase) (from Supertechs, Bethesda, MD). In every case, formalin-fixed tissue was subjected to heat-induced antigen retrieval.

\section{PCR Analysis for Immunoglobulin and T Cell Receptor Gene Rearrangements}

In 21 cases of ES, DNA was extracted from formalin-fixed, paraffin-embedded tissue. Two to three 50 micron-thick sections were placed in a 

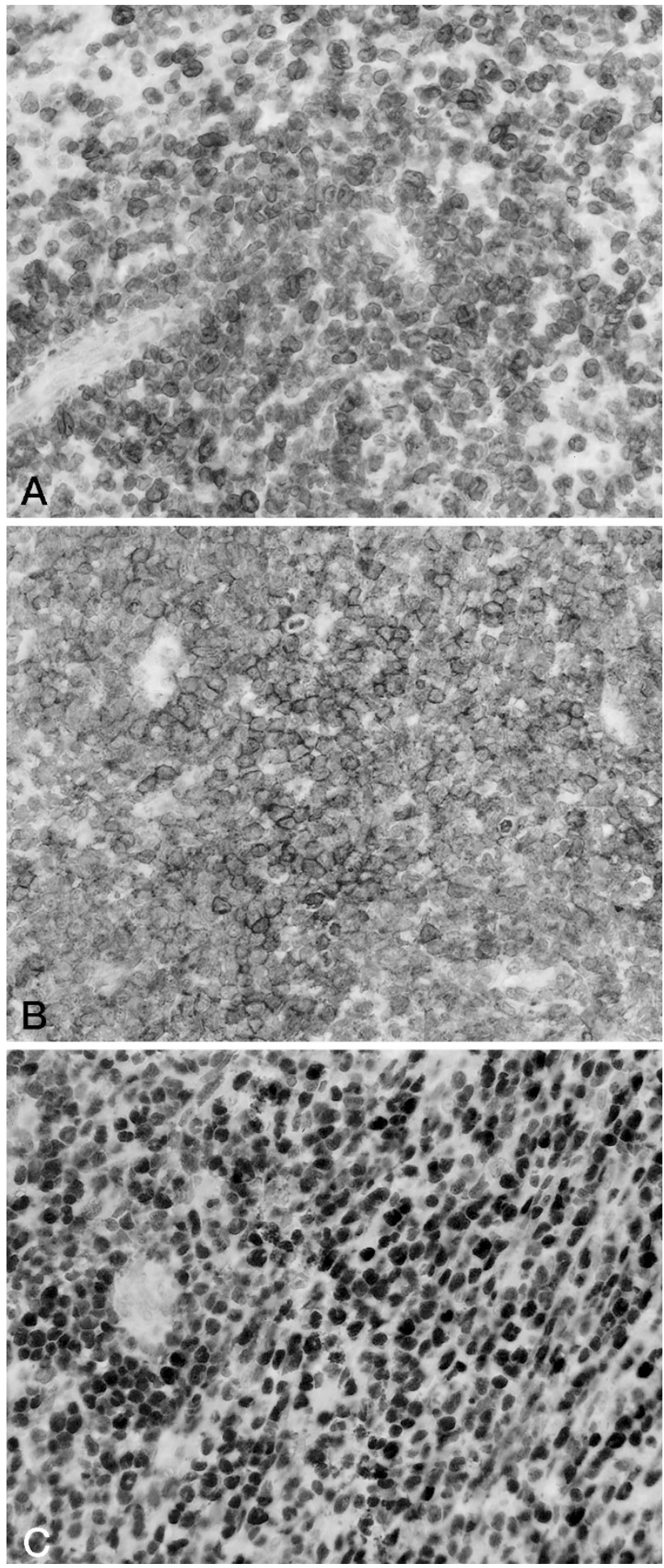

FIGURE 3. Lymphoma cells are positive for CD79a (A) $(\times 400)$, CD43 (B) $(\times 400)$, and $\operatorname{TdT}(\mathbf{C})(\times 400)$.

sterile Eppendorf tube, deparaffinized with xylene, washed with $100 \%$ ethanol and then $70 \%$ ethanol, and digested with proteinase $\mathrm{K}$ overnight at $55^{\circ} \mathrm{C}$. DNA was extracted with phenol-chloroformisoamyl alcohol (25:24:1), precipitated with $3 \mathrm{~m} \mathrm{so-}$ dium acetate and $100 \%$ ethanol and reconstituted with $100 \mu$ l sterile water.
The PCR for immunoglobulin heavy chain gene rearrangement and T-cell receptor gamma chain gene rearrangement was performed as previously described (8) in a Gene Amp 9600 Thermal Cycler (Perker Elmer, Norwalk, CT) using consensus primers specific for the variable and joining regions of the immunoglobulin heavy chain gene (9) and consensus primers specific for the variable and joining regions of the TCR gamma chain gene (10). The PCR products were analyzed by polyacrylamide gel electrophoresis containing 10 to $15 \%$ polyacrylamide gels.

\section{RESULTS}

\section{Clinical Features}

There were 17 females and 16 males. The ages ranged from 7 to 60 years, with a mean age of 29.3 years. Tumors were located in the bone or soft tissue of the extremities in 17 cases and in the trunk in 16 cases. All except one case were localized to one site at the time of diagnosis. The most common soft tissue sites included the chest wall (four cases), retroperitoneum (three cases), and thigh (three cases). The most common bones involved were the femur (two cases) and tibia (two cases).

\section{Histologic Features}

Morphologically, all cases fit the ES spectrum by light microscopy. Some cases had classic features of ES including a sheet-like growth pattern of small uniform blue cells, separated by fibrous septa. These cases exhibited geographic necrosis and pseudorosette formation (Fig. 4). Other cases had focal areas of discohesion, irregular nuclear contours, crush artifact, and a "fried egg" appearance; these latter features suggested lymphoma (Fig. 5).

\section{Immunohistochemistry and Polymerase Chain Reaction}

The results of the immunohistochemical analysis are summarized in Table 1. All cases were negative for lymphoid markers (LCA, CD3, CD20, CD43, CD79a, and TdT). CD99 was positive in 31/33 and bcl-2 was weakly positive in 13/33. 29 cases studied with CD10, 31 cases studied with CD34 and eight cases studied with UCHL-1 were negative for these markers.

Gene rearrangements by PCR on all 21 cases were negative for the IgH chain gene rearrangement and TCR gamma chain gene rearrangement (Fig. 6). In addition, five cases that were positive for bcl-2 by immunohistochemistry were also analyzed for the $\mathrm{t}(14 ; 18)$ translocation by PCR; however, no bcl-2/ immunoglobulin heavy chain gene rearrangements were identified. 


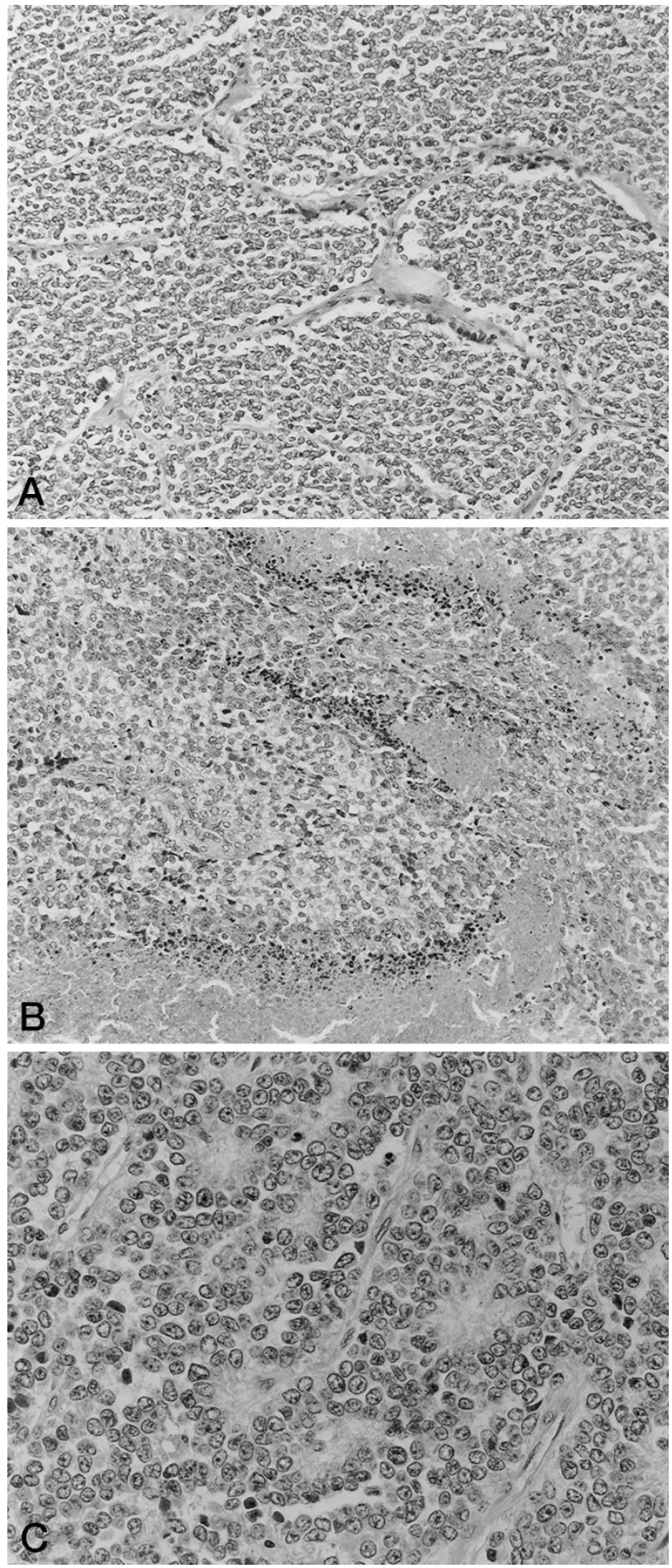

FIGURE 4. Classic features of Ewing's sarcoma: sheet-like growth pattern separated by fibrous septa $(\mathbf{A})(\times 100)$, geographic necrosis $(\mathbf{B})$ $(\times 100)$, and pseudorosette formation $(\mathbf{C})(\times 400)$.

\section{DISCUSSION}

Based on our sentinel case of a precursor B-lymphoblastic lymphoma that was initially mistaken for Ewing's sarcoma because of confusing morphologic and immunohistochemical findings (1), we wanted to see whether the reverse might be
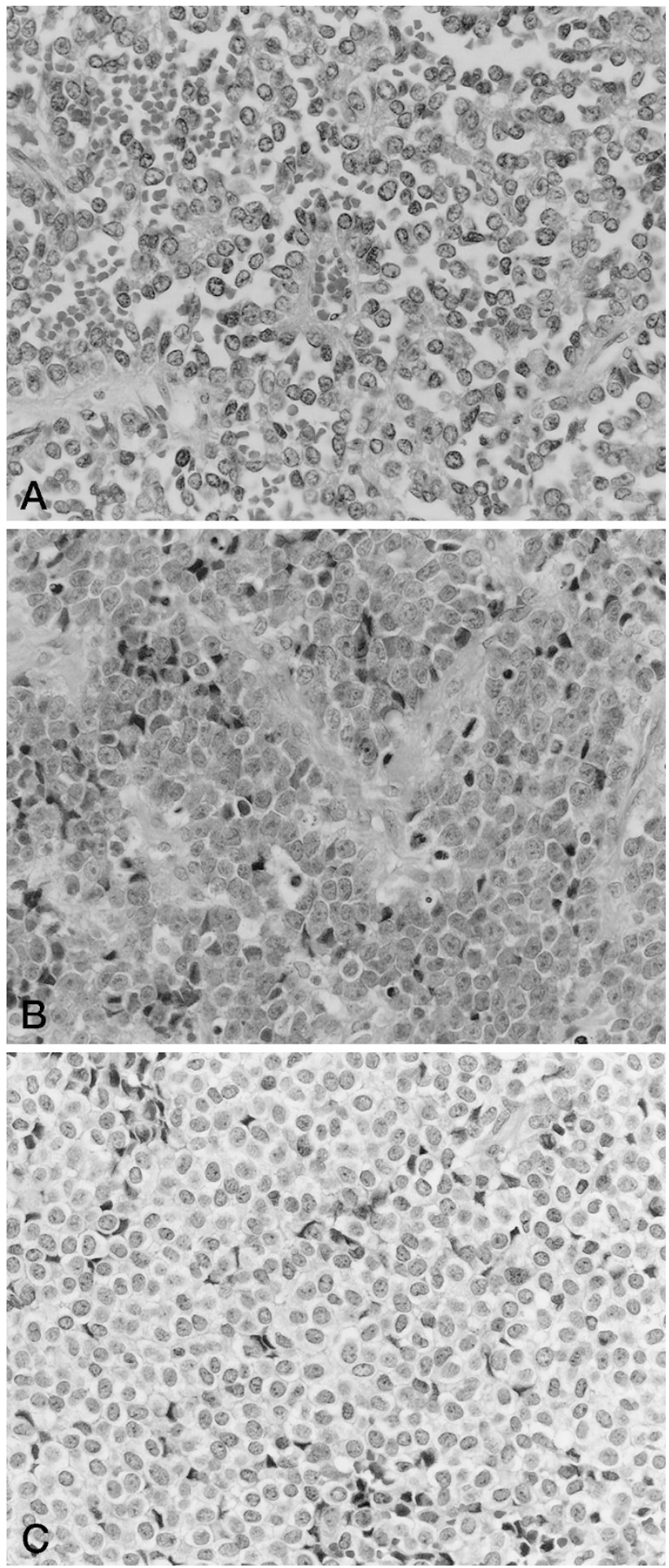

FIGURE 5. ES with focal areas mimicking malignant lymphoma discohesion $(\mathbf{A})(\times 400)$, irregular nuclear contours $(\mathbf{B})(\times 400)$, and "fried egg" appearance $(\mathbf{C})(\times 400)$.

true and to determine further evidence to separate Ewing's sarcoma from precursor B-lymphoblastic lymphoma. Therefore, we studied known Ewing's sarcoma (ES) cases from bone and soft tissue for immunohistochemical and molecular identifiers of lymphoma. Both ES and lymphoma belong to a similar morphologic family of small round cell tu- 
TABLE 1. Summary of the Immunohistochemical Analysis

\begin{tabular}{lc}
\hline \multicolumn{1}{c}{ Antibody } & $\begin{array}{c}\text { Number of } \\
\text { Positive Cases }\end{array}$ \\
\hline CD99 & $31 / 33$ \\
CD45 & $0 / 33$ \\
CD20 & $0 / 33$ \\
CD79a & $0 / 33$ \\
CD3 & $0 / 33$ \\
CD43 & $0 / 33$ \\
TdT & $0 / 33$ \\
CD10 & $0 / 29$ \\
CD34 & $0 / 31$ \\
CD45RO & $0 / 8$ \\
Bcl-2 & $13 / 33$ \\
Keratins & $0 / 27$ \\
EMA* & $1 / 10$ \\
S-100* & $4 / 24$ \\
HMB-45 & $0 / 10$ \\
Desmin & $0 / 19$ \\
Actin & $0 / 10$ \\
NSE* & $8 / 22$ \\
Synaptophysin* & $4 / 17$ \\
Chromogranin* & $1 / 15$ \\
Neurofilament* & $1 / 8$ \\
Vimentin & $10 / 13$ \\
Leu 7 & $2 / 8$ \\
\hline
\end{tabular}

a. All the cases morphologically fit the spectrum of Ewing's sarcoma/ primitive neuroectodermal tumor. Lymphoid antibodies used were the following: CD45 (LCA), CD20 (L26), CD79a (Mb-1), CD3, CD43 (Leu 22), CD99 (O-13), CD45RO (UCHL-1), CD10 and CD34.

* Denotes focal positivity in some of the cases.

mors. We equate Ewing's sarcoma as on a spectrum with primitive neuroectodermal tumor (PNET), because both lesions have similar clinical, pathologic, and molecular findings $(t(11 ; 22))$. Other small blue cell tumors include small cell osteosarcoma, mesenchymal chondrosarcoma, embryonal rhabdomyosarcoma, neuroblastoma, desmoplastic small round cell tumor, and neuroendocrine carcinomas. The correct diagnosis of intraosseous small round cell tumors, particularly in children, may pose extreme difficulty because of overlapping clinical, radiographic, histologic, and immunophenotypic features $(3,4)$.

Ewing's sarcoma (including PNET) is the most common intraosseous small round cell tumor, and constitutes approximately $70 \%$ of these cases (11), whereas bone lymphomas account for approximately $5 \%$ of all primary bone tumors (12-14). Both of these tumors also may present as primary soft tissue tumors, however, very rarely (15-17). In children, intraosseous lymphoblastic lymphoma comprises a significant percentage of the lymphoma cases and is often misdiagnosed. For example, in a study of 11 bone lymphomas, 10 of 11 cases were referred with a diagnosis other than lymphoma (4). Among these, ES was the most common erroneous diagnosis.

Multiple factors can contribute to the frequent misdiagnosis of B-LBL as Ewing's sarcoma. When interpreted in isolation, histology, cytochemistry, immunohistochemistry, and even molecular tests

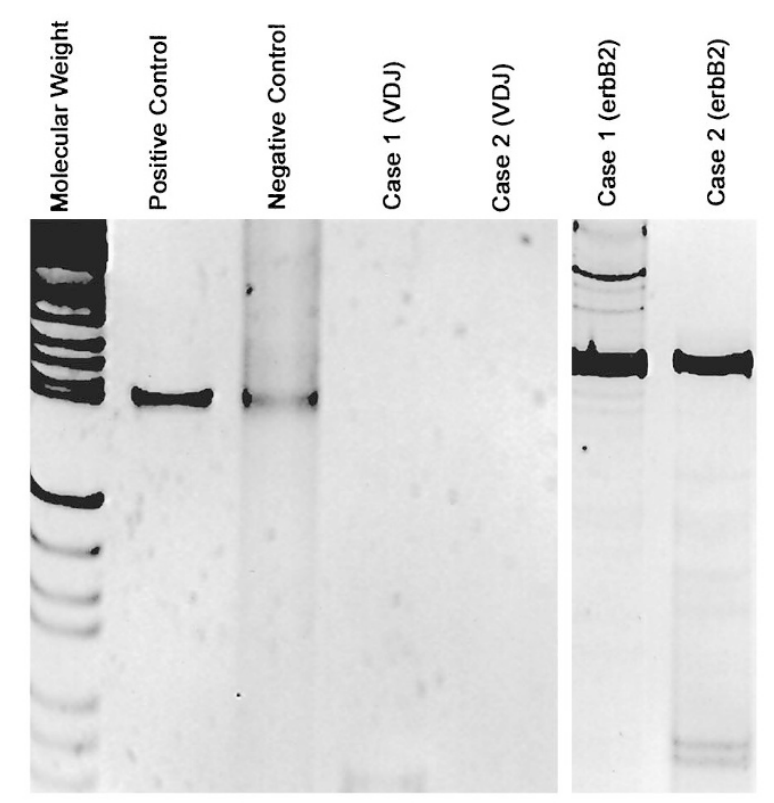

A

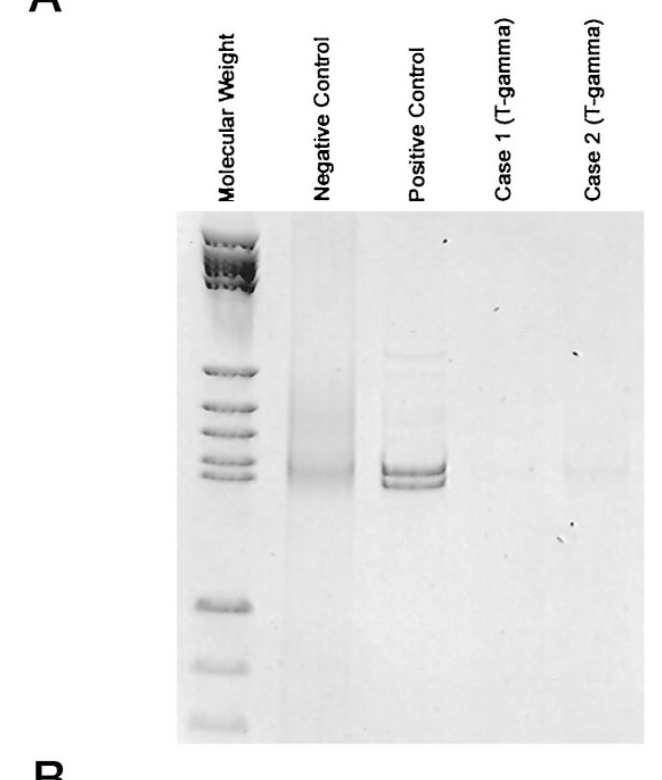

FIGURE 6. Negative polymerase chain reaction for immunoglobulin heavy chain (A) and T cell receptor gamma chain gene rearrangements (B) in two cases of ES. ErbB-2 was used to show the presence of amplifiable DNA in each case. DNA from tonsillectomy specimens was the negative control and DNA from lymph node specimens from patients with known B- or T-cell lymphomas was the positive control.

may result in a diagnostic error. Some of the histologic features that are often present in Ewing's sarcoma and may be present in lymphoma include crush artifact, overlapping nuclei, abundant geographic necrosis with perivascular tumor preservation, an alveolar growth pattern, focal discohesiveness, and rosette-like structures (18). The presence of scant cytoplasm, irregular nuclei, finely dispersed nuclear chromatin, and inconspicuous nucleoli in tumor cells, the presence of background mature small lymphocytes and plasma cells among 
tumor cells, and sclerosis are often features that strongly suggest B-LBL. Cytochemical stains may be also misinterpreted. The presence of intracytoplasmic glycogen as determined by the periodic acidSchiff stain with diastase digestion is sometimes used to distinguish ES from lymphoma. However, glycogen can be found in lymphoma (19).

Immunohistochemistry is potentially the most reliable diagnostic aid in the differential diagnosis of ES and lymphoma. However, a limited immunohistochemical panel may cause diagnostic pitfalls as well. In many institutions, the initial immunohistochemical panel for a small round cell tumor includes CD45, vimentin, keratin, desmin, synaptophysin, S-100 protein, neuron-specific enolase, chromogranin and CD99 (MIC2 gene product). Our experience suggests that this panel is not sufficient; B-LBL is frequently negative for CD45 and CD20, and may express antigens that are positive in Ewing's sarcoma including vimentin (20), CD99 (21$23)$ and rarely cytokeratin $(1,24)$. CD99 was initially reported to be specific for Ewing's sarcoma (25), but is now known to be frequently positive in both $B$ and T cell type LBL (21-23). Positive staining for keratin also needs to be interpreted cautiously. Among the small round cell tumors, desmoplastic small round cell tumors often express keratin (26, 27) and ES may also show focal positivity for keratin (28, 29). Thus, even a CD45-, CD20-, vimentin+, keratin + immunophenotype does not exclude the diagnosis of B-LBL.

For positive identification of B-LBL, TdT, CD79a, and CD43 are the most useful markers in LCA- and CD20-negative cases. Because both precursor B and T cell type LBL are almost always positive for TdT (30), immunohistochemical demonstration of TdT, which can be done reliably on paraffin-embedded tissue, is the most sensitive and specific for a diagnosis of LBL, even though TdT positivity was observed in nonhematopoietic small round cell tumors in a previous study (31). In that study, 7 of 10 medulloblastoma, 1 of 19 rhabdomyosarcoma and 1 of 8 ES cases were found to express TdT, although we did not find TdT positivity in this study of 33 ES cases. Moreover, in a recent study, TdT was reported to be negative in $17 \mathrm{ES}$ cases (5). CD3 is the most useful marker for identifying a T-cell lineage. CD79a is the most sensitive paraffin marker for B-cell lineage because it is expressed in early $B$ cells as well as all of the other stages of B cell differentiation, including plasma cells (32). B-LBL is often CD20 negative $(1,2,32,33)$. Similarly, CD45RO (UCHL-1) is often negative in immature T-lymphoblasts (33). CD43 is a very reliable marker for immature hematopoietic neoplasms, because anti-CD43 antibodies (Leu 22 or MT-1) will stain not only T-cell LBL, but also $80 \%$ of B-LBL and almost all of granulocytic sarcomas (34). In this study we found that TdT, CD79a and CD43 are all negative in ES and therefore these three stains should be included in the differential diagnosis between Ewing's sarcoma and B-LBL. These findings were confirmed by a recent study of 17 ES cases (5). Two other useful markers that could help distinguishing LBL and ES are CD10 and CD34. Both are commonly used in flow cytometric analysis of leukemias and are often positive in precursor B-lymphoblastic lymphoma/leukemias (35, 36). Because paraffin antibodies are available for these markers, positive identification for any of these should alert the pathologist to the possibility of LBL because in this study, all the ES cases studied for these markers (31 cases for CD34 and 29 cases for CD10) lacked these antigens.

Molecular genotyping, especially using PCR, may be very helpful in the diagnosis of malignant lymphomas that cannot be diagnosed based on morphology and immunohistochemistry (37). Precursor lymphoblastic lymphomas or lymphoblastic leukemias commonly rearrange their immunoglobulin heavy chain (IgH) and/or $\mathrm{T}$ cell receptor gamma chain $(\mathrm{T} \gamma)$ genes, irrespective of their lineage. B-LBLs demonstrate IgH gene rearrangement in $90 \%$ and $\mathrm{T} \gamma$ gene rearrangement in $50 \%$ of cases. Similarly, T-LBLs demonstrate $\mathrm{T} \gamma$ gene rearrangement in more than 90 and IgH gene rearrangement in up to $25 \%$ of cases $(38,39)$. The clonal IgH or T $\gamma$ gene rearrangements are specific for lymphomas and can be demonstrated by PCR in up to $90 \%$ of cases utilizing more than one set of primers (3739). We studied 21 cases of Ewing's sarcoma for IgH and $\mathrm{T} \gamma$ gene rearrangements and did not observe any false positive rearrangements. Thus, the demonstration of clonal gene rearrangement of IgH or $\mathrm{T} \gamma$ by PCR, which can be performed on paraffinembedded tissue, supports the diagnosis of lymphoma or lymphoblastic leukemia rather than Ewing's sarcoma in equivocal cases.

Approximately 85\% of Ewing's sarcoma and PNET are characterized by $\mathrm{t}(11 ; 22)(\mathrm{q} 24 ; \mathrm{q} 12)$ translocation that causes fusion of the EWS gene on chromosome 22 to the FL-1 gene on chromosome 11 (40). Another common translocation present in approximately $10 \%$ of ES/PNET is $\mathrm{t}(21 ; 22)(\mathrm{q} 22 ; \mathrm{q} 12)$ resulting in EWS/ ERG gene fusion. Other rarer translocations include $\mathrm{t}(7 ; 22)(\mathrm{p} 22 ; \mathrm{q} 12)$ resulting in EWS/ETV-1; $\mathrm{t}(17 ; 22)$ (q12; q12) resulting in EWS/E1AF and $\mathrm{t}(2 ; 22)$ (q33; q12) resulting in EWS/FEV (40). EWS/FL-1 fusion transcript caused by $\mathrm{t}(11 ; 22)(\mathrm{q} 24 ; \mathrm{q} 12)$ is specific for $\mathrm{ES} / \mathrm{PNET}$ and is not found in other small round cell tumors of infancy $(41,42)$. Moreover, this translocation can be demonstrated in up to $80 \%$ of ES/PNET by reverse transcriptase-PCR from mRNA isolated from fresh or formalin-fixed, paraffin-embedded tissue (41-44). Interestingly, one reported case of acute myeloid leukemia had $\mathrm{t}(11 ; 22)(\mathrm{q} 24 ; \mathrm{q} 12)$ translocation by cytogenetic analysis (45), but it is not known whether 
that case contained EWS/FL-1 fusion transcript, because the case was not studied at the molecular level.

In conclusion, light microscopy and a limited panel of immunohistochemical markers can cause misdiagnosis of small round cell tumors and to prevent this, immunohistochemical markers should include CD79a, CD43, TdT, CD10 and CD34 if lymphoma is suspected, in addition to other routine markers. None of these markers were seen in ES cases we studied. In controversial cases, gene rearrangement by PCR also can be of great value. Positive IgH-R or TCR-R, never positive in Ewing's sarcoma, will support the diagnosis of lymphoma or lymphoblastic leukemia. Similarly demonstration of EWS/FL-1 fusion transcript by RTPCR will support the diagnosis of ES/PNET.

Although rare, precursor B-LBL should be always considered in the differential diagnosis of small round cell tumors of bone. A diagnosis of Ewing's sarcoma should be made only after complete immunophenotyping, and if necessary, molecular diagnostic tests to exclude LBL, because lymphoblastic lymphoma is a potentially curable disease with aggressive chemotherapy alone $(46,47)$.

Acknowledgments: The authors are grateful to Ayanna Wooding for her excellent laboratory assistance.

\section{REFERENCES}

1. Ozdemirli M, Fanburg-Smith JC, Hartmann DP, Shad AT, Lage JM, Magrath IT, et al. Precursor B-Lymphoblastic lymphoma presenting as a solitary bone tumor and mimicking Ewing's sarcoma: a report of four cases and review of the literature. Am J Surg Pathol 1998;22:795-804.

2. Iravani S, Singleton TP, Ross CW, Schnitzer B. Precursor B lymphoblastic lymphoma presenting as lytic bone lesions. Am J Clin Pathol 1999;112:836-43.

3. Dehner LP. On trial: a malignant small cell tumor in a child. Four wrongs do not make a right. Am J Clin Pathol 1998;109: 662-8.

4. Furman WL, Fitch S, Hustu HO, Callihan T, Murphy SB. Primary lymphoma of bone in children. J Clin Oncol 1989; 7:1275-80.

5. Lucas DR, Bentley G, Dan ME, Tabaczka P, Poulik JM, Mott MP. Ewing sarcoma vs lymphoblastic lymphoma. A comparative immunohistochemical study. Am J Clin Pathol 2001; 115:11-7.

6. Andres TL, Kadin ME. Immunologic markers in the differential diagnosis of small round cell tumors from lymphocytic lymphoma and leukemia. Am J Clin Pathol 1983;79:546-52.

7. Hsu S-M, Raine L, Fanger H. Use of avidin-peroxidase complex $(\mathrm{ABC})$ in immunoperoxidase techniques: a comparison between $\mathrm{ABC}$ and unlabeled antibody procedures. J Histochem Cytochem 1981;29:557-80.

8. Sioutos N, Bagg A, Michaud GY, Irving SG, Hartmann DP, Siragy $\mathrm{H}$, et al. Polymerase chain reaction versus Southern blot hybridization. Detection of immunoglobulin heavychain gene rearrangements. Diag Mol Pathol 1995;4:8-13.

9. McCarthy KP, Sloane JP, Wiedemann LM. Rapid method for distinguishing clonal from polyclonal B cell populations in surgical biopsy specimens. J Clin Pathol 1990;43:429-32.
10. Benhattar J, Delacretaz F, Martin P, Chaubert P, Costa J. Improved polymerase chain reaction detection of clonal T-cell lymphoid neoplasms. Diagn Mol Pathol 1995;4:10812.

11. Llombart-Bosch A, Blache R, Peydro-Olaya A. Round-cell sarcomas of bone and their differential diagnosis (with particular emphasis on Ewing's sarcoma and reticulosarcoma). A study of 233 tumors with optical and electron microscopic techniques. Pathol Annu 1982;17:113-45.

12. Clayton F, Butler JJ, Ayala AG, Ro JY, Zornoza J. NonHodgkin's lymphoma in bone. Pathologic and radiologic features with clinical correlates. Cancer 1987;60:2494-501.

13. Dahlin DC. Bone tumors. General aspects and data on 6221 cases. 3rd ed. Springfield, IL: Charles C Thomas; 1978.

14. Ostrowski ML, Unni KK, Banks PM, Shives TC, Evans RG, O'Connell MJ, et al. Malignant lymphoma of bone. Cancer 1986;58:2646-55.

15. Guiter GE, Gamboni MM, Zakowski MF. The cytology of extraskeletal Ewing sarcoma. Cancer 1999;87:141-8.

16. Damron TA, Le MH, Rooney MT, Vermont A, Poiesz BJ. Lymphoma presenting as a soft tissue mass. A soft tissue sarcoma simulator. Clin Orthop 1999;360:221-30.

17. Travis WD, Banks PM, Reiman HM. Primary extranodal soft tissue lymphoma of the extremities. Am J Surg Pathol 1987; 11:359-66.

18. Frizzera G, Gajl-Peczalska K, Sibley RK, Rosai J, Cerhwitz D, Hurd DD. Rosette formation in malignant lymphoma. Am J Pathol 1985;119:351-6.

19. Mierau GW, Berry PJ, Orsini EN. Small round cell neoplasms: can electron microscopy and immunohistochemical studies accurately classify them? Ultrastr Pathol 1985; 9:99-111.

20. Giorno R, Sciotto CG. Use of monoclonal antibodies for analyzing the distribution of the intermediate filament protein vimentin in human non-Hodgkin's lymphomas. Am J Pathol 1985;120:351-5.

21. Riopel M, Dickman PS, Link MP, Perlman EJ. MIC2 analysis in pediatric lymphomas and leukemias. Hum Pathol 1994; 25:396-9.

22. Stevenson AJ, Chatten J, Bertoni F, Miettinen M. CD99 (p30/ 32mic2) Neuroectodermal/Ewing's sarcoma antigen as an immunohistochemical marker. Review of more than 600 tumors and the literature experience. Appl Immunohistochem 1994;2:231-40.

23. Robertson PB, Neiman RS, Worapongpaiboon S, John K, Orazi A. O13 (CD99) positivity in hematologic proliferations correlates with TdT positivity. Mod Pathol 1997;10:277-82.

24. Lasota J, Hyjek E, Koo CH, Blonski J, Miettinen M. Cytokeratin-positive large-cell lymphomas of B-cell lineage. A study of five phenotypically unusual cases verified by polymerase chain reaction. Am J Surg Pathol 1996;20:34654 .

25. Weidner N, Tjoe J. Immunohistochemical profile of monoclonal antibody O13: antibody that recognizes glycoprotein p30/32MIC2 and is useful in diagnosing Ewing's sarcoma and peripheral neuroepithelioma. Am J Surg Pathol 1994;18: 486-94.

26. Dorsey BV, Benjamin LE, Rauscher F, Klencke B, Venook AP, Warren RS, et al. Intra-abdominal desmoplastic small round-cell tumor: expansion of the pathologic profile. Mod Pathol 1996;9:703-9.

27. Gerald WL, Miller HK, Battifora H, Miettinen M, Silva EG, Rosai J. Intra-abdominal desmoplastic small round-cell tumor. Report of 19 cases of a distinctive type of high-grade polyphenotypic malignancy affecting young individuals. Am J Surg Pathol 1991;15:499-513.

28. Dehner LP. Primitive neuroectodermal tumor and Ewing's sarcoma. Am J Surg Pathol 1993;17:1-13.

29. Gu M, Antonescu CR, Guiter G, Huvos AG, Ladanyi M, Zakowski MF. Cytokeratin immunoreactivity in Ewing's sar- 
coma: prevelance in 50 cases confirmed by molecular diagnostic studies. Am J Surg Pathol 2000;24:1174-5.

30. Orazi A, Cattoretti G, John K, Neiman RS. Terminal deoxynucleotidyl transferase staining of malignant lymphomas in paraffin sections. Mod Pathol 1994;7:582-6.

31. Matthewson RC, Kjeldsberg CR, Perkins SL. Detection of terminal deoxynucleotidyl transferase (TdT) in nonhematopoietic small round cell tumors of children. Pediatr Pathol Lab Med 1997;17:835-44.

32. Mason DY, Cordell JL, Brown MH, Borst J, Jones M, Pulford $\mathrm{K}$, et al. CD79a: a novel marker for B-cell neoplasms in routinely processed tissue samples. Blood 1995;86:1453-9.

33. Kurec AS, Cruz VE, Barrett D, Mason DY, Davey FR. Immunophenotyping of acute leukemias using paraffin-embedded tissue sections. Am J Clin Pathol 1990;93:502-9

34. Quintanilla-Martinez L, Zukerberg LR, Ferry JA, Harris NL. Extramedullary tumors of lymphoid or myeloid blasts. The role of immunohistology in diagnosis and classification. Am J Clin Pathol 1995;104:431-43.

35. Weir EG, Borowitz MJ. Flow cytometry in the diagnosis of acute leukemia. Semin Hematol 2001;38:124-38.

36. Stetler-Stevenson M, Braylan RC. Flow cytometric analysis of lymphomas and lymphoproliferative disorders. Semin Hematol 2001;38:111-23.

37. Cossman J, Zehnbauer B, Garrett CT, Smith LJ, Williams M, Jaffe ES, et al. Gene rearrangements in the diagnosis of lymphoma/leukemia. Guidelines for use based on a multiinstitutional study. Am J Clin Pathol 1991;95:347-54.

38. Medeiros LJ, Bagg A, Cossman J. Molecular genetics in the diagnosis and classification of lymphoid neoplasms. In: Jaffe ES, ed. Surgical pathology of the lymph nodes and related organs. 2nd ed. Philadelphia: W.B. Saunders; 1995. p. 58-97.

39. Macintyre EA, Delabesse E. Molecular approaches to the diagnosis and evaluation of lymphoid malignancies. Semin Hematol 1999;36:373-89.
40. De Alava E, Gerald WL. Molecular biology of the Ewing's sarcoma/primitive neuroectodermal tumor family [review]. J Clin Oncol 2000;18:204-13.

41. Downing JR, Head DR, Parham DM, Douglass EC, Hulshof MG, Link MP, et al. Detection of the $(11 ; 22)(\mathrm{q} 24 ; \mathrm{q} 12)$ translocation of Ewing's sarcoma and peripheral neuroectodermal tumor by reverse transcription polymerase chain reaction. Am J Pathol 1993;143:1294-300.

42. Sorensen PH, Liu XF, Delattre O, Rowland JM, Biggs CA, Thomas G, Triche TJ. Reverse transcriptase PCR amplification of EWS/FLI-1 fusion transcripts as a diagnostic test for peripheral primitive neuroectodermal tumors of childhood. Diagn Mol Pathol 1993;2:147-57.

43. Adams V, Hany MA, Schmid M, Hassam S, Briner J, Niggli FK. Detection of $\mathrm{t}(11 ; 22)(\mathrm{q} 24 ; \mathrm{q} 12)$ translocation breakpoint in paraffin-embedded tissue of the Ewing's sarcoma family by nested reverse transcription-polymerase chain reaction. Diagn Mol Pathol 1996;5:107-13.

44. De Alava E, Lozano MD, Patino A, Sierrasesumaga L, PardoMindan FJ. Ewing family tumors: potential prognostic value of reverse-transcriptase polymerase chain reaction detection of minimal residual disease in peripheral blood samples. Diagn Mol Pathol 1998;7:152-7.

45. Hawkins JM, Craig JM, Secker-Walker LM, Prentice HG, Mehta AB. Ewing's sarcoma $t(11 ; 22)$ in a case of acute nonlymphocytic leukemia. Cancer Genet Ctyogenet 1991; 55:157-61.

46. Haddy TB, Keenan AM, Jaffe ES, Magrath IT. Bone involvement in young patients with non-Hodgkin's lymphoma: efficacy of chemotherapy without local radiotherapy. Blood 1988;72:1141-7.

47. Loeffler JS, Tarbell NJ, Kozakewich H, Cassady JR, Weinstein HJ. Primary lymphoma of bone in children: analysis of treatment results with adriamycin, prednisone, oncovin (APO), and local radiation therapy. J Clin Oncol 1986;4:496-501. 